\title{
Thermochemical hydrogen production from water using reducible oxide materials: a critical review
}

\author{
Lawrence D'Souza
}

Received: 17 September 2012/ Accepted: 3 January 2013/Published online: 1 February 2013

(C) The Author(s) 2013. This article is published with open access at Springerlink.com

\begin{abstract}
This review mainly focuses on summarizing the different metal oxide systems utilized for water-splitting reaction using concentrated solar energy. Only two or three cyclic redox processes are considered. Particle size effect on redox reactions and economic aspect of hydrogen production via concentrated solar energy are also briefly discussed. Among various metal oxides system $\mathrm{CeO}_{2}$ system is emerging as a promising candidate and researchers have demonstrated workability of this system in the solar cavity-receiver reactor for over 500 cycles. The highest solar thermal process efficiency obtained so far is about $0.4 \%$, which needs to be increased for real commercial applications. Among traditionally studied oxides, thin-film ferrites looks more promising and could meet US Department of energy target of $\$ 2.42 / \mathrm{kg} \mathrm{H}_{2}$ by 2025 . The cost is mainly driven by high heliostat cost which needs to reduced significantly for economic feasibility. Overall, more work needs to be done in terms of redox material engineering, reactor technology, heliostat cost reduction and gas separation technologies before commercialization of this technology.
\end{abstract}

Keywords Hydrogen · Water splitting - Solar thermal

\section{Introduction}

Hydrogen is considered as next generation fuel to propel airplanes, automotive vehicles and virtually any stationary

L. D’Souza $(\bowtie)$

SABIC Corporate Research and Innovation Center (CRI)

at KAUST, Saudi Basic Industries Corporation, P.O. Box

4545-4700, Thuwal 23955-6900, Saudi Arabia

e-mail: dsouzal@sabic.com power system using fuel cells. The non-polluting byproduct 'water' upon hydrogen combustion has attracted world attention to save ever polluting earth environment for sustainable future. Currently, the hydrogen is derived from fossil fuels. The smallest molecule of universe sees highest demand due to its non-polluting end product as well as its remarkable chemical and physical properties. There are number of chemical transformation in which hydrogen is used as hydrogenating or reducing agent. Moreover, present trend to harvest $\mathrm{CO}_{2}$ into useful chemicals demands hydrogen. Many scientists around the world are pessimistic about $\mathrm{CO}_{2}$ hydrogenation since they see raising demand for hydrogen and currently there are no real alternatives to fulfill other than fossil fuels. Researchers have been looking at different possibilities to generate hydrogen by biological and chemical means. Electrolysis of water is one of the easy and greener route to generate hydrogen only if electricity comes from wind, tidal, photovoltaics, geothermal or hydropower. The other greener routes are photoelectrochemical water splitting [1], by direct splitting of water [2,3] and solar thermochemical cycles. It is hoped that combination of several technologies can fulfill future hydrogen demand.

Water splitting by low valent metal oxides at high temperature is one of the clean way of hydrogen production since the temperature needed to perform chemical reaction comes from concentrated solar thermal heat. Though the technology is known since more than three decades commercial realization is yet to happen due to numerous challenges in this technology. The off-sun hours, cloudy and rainy seasons are main drawbacks for commercial realization. Moreover, technology cannot be implemented in geographically poor sun receiving regions.

This review summarizes the work done in high-temperature hydrogen production via two-step redox processes 
using various metal oxides (Table 1). Only the high-temperature experiments demonstrated either in solar furnace or in laboratory fixed-bed reactor have been considered. This review does not cover the hybrid technologies or other forms of hydrogen production technologies.

Bilgen et al. [4] have demonstrated the possibility of splitting water directly at high temperature. The theoretical calculation for the said reaction is depicted in Fig. 1. It was found that the amount of hydrogen produced decreases with increase in $\mathrm{H}_{2} \mathrm{O}$ partial pressure. Figure 1 gives the compounded results for partial pressure of water equal to 0.1 bar between 1,500 and 5,000 K. Bilgen [4] experimentally demonstrated that between 2,273 and $2,773 \mathrm{~K}$ formation of about 2-3\% $\mathrm{H}_{2}$ when mixture of steam and argon was passed in the crucible at the focus of the solar furnace.

The dissociation of metal oxide to their respective metal is written as follows [14]:

$\mathrm{M}_{x} \mathrm{O}_{y}=x \mathrm{M}+\frac{y}{2} \mathrm{O}_{2}$.

The temperature required for few metal oxides conversion to their metallic form is given in Table 2 . Except for $\mathrm{ZnO}$, achieving temperature needed to reduce metal oxide to their metallic form is practically impossible due to the high temperature required. Concentration ratios of up to 10,000 suns have been achieved by researchers which translate to $3,800 \mathrm{~K}$. But high-temperature operation, reactor material thermal stability and radiation heat losses makes the process almost impossible. The temperature required to attain $\Delta G^{\circ}$ of the reaction (1) equals zero can be substantially brought down by the use of hydrocarbon as reducing agents, for example graphite or methane, which can be written as follows:

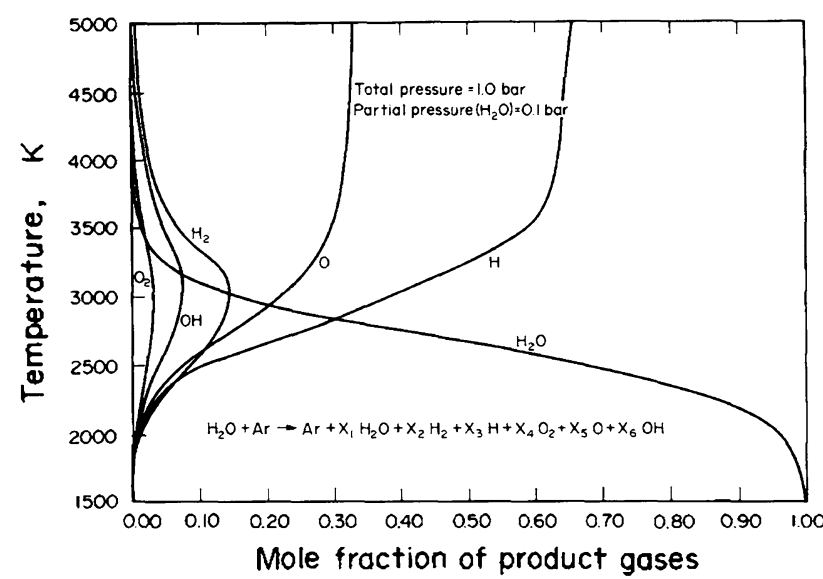

Fig. 1 Theoretical composition of the different products in the dissociation of water at high temperature; total pressure is 1 bar and partial pressure of $\mathrm{H}_{2} \mathrm{O}$ is 0.1 bar

$$
\begin{aligned}
& \mathrm{M}_{x} \mathrm{O}_{y}+y \mathrm{C}(\mathrm{gr})=x \mathrm{M}+y \mathrm{CO} \\
& \mathrm{M}_{x} \mathrm{O}_{y}+y \mathrm{CH}_{4}=x \mathrm{M}+y\left(2 \mathrm{H}_{2}+\mathrm{CO}\right) .
\end{aligned}
$$

Two-step cyclic redox processes are simplest way of producing hydrogen by utilizing metal oxide. The solar reduction step is endothermic and can be written as shown in (4),

$\frac{1}{\Delta \delta} \mathrm{M}_{x} \mathrm{O}_{y-\delta_{o x}} \rightarrow \frac{1}{\Delta \delta} \mathrm{M}_{x} \mathrm{O}_{y-\delta_{\text {red }}}+0.5 \mathrm{O}_{2}$

$\frac{1}{\Delta \delta} \mathrm{M}_{x} \mathrm{O}_{y-\delta_{\text {red }}}+\mathrm{H}_{2} \mathrm{O} \rightarrow \frac{1}{\Delta \delta} \mathrm{M}_{x} \mathrm{O}_{y-\delta_{o x}}+\mathrm{H}_{2}$

$\frac{1}{\Delta \delta} \mathrm{M}_{x} \mathrm{O}_{y-\delta_{\text {red }}}+\mathrm{CO}_{2} \rightarrow \frac{1}{\Delta \delta} \mathrm{M}_{x} \mathrm{O}_{y-\delta_{\text {ox }}}+\mathrm{CO}$

(where $\delta$ is non-stoichiometric coefficient and $\Delta \delta$ is change in non-stoichiometric coefficient).

The reaction (4) takes place at temperature above $1,000 \mathrm{~K}$ and many metal oxide systems have been studied over the past four decades. Several two- and three-step $\mathrm{H}_{2} \mathrm{O}$-splitting thermochemical cycles based on metal oxides redox reactions have been reported in the literature. Nakamura [5] first proposed the two-step redox cycle in 1977 for $\mathrm{Fe}_{3} \mathrm{O}_{4} / \mathrm{FeO}$ redox cycle; interest then diminished for the next two decades and thereafter a spurt of interest resulted in investigation of several other oxide systems for thermochemical redox cycle for hydrogen generation. The high temperature required for reduction reaction can be supplied by either concentrated solar energy or fossil fuels. The solar reduction is usually carried out in the presence of an inert gas, if a reducing gas is used the reduction temperature can be brought down substantially. The reduced metal oxide can be oxidized back to the original state by oxidants like $\mathrm{H}_{2} \mathrm{O}$ or $\mathrm{CO}_{2}$. If $\mathrm{H}_{2} \mathrm{O}$ is used $\mathrm{H}_{2}$ can be produced and if $\mathrm{CO}_{2}$ is used $\mathrm{CO}$ can be produced as shown in Eqs. (5) and (6), respectively. If $\mathrm{H}_{2} \mathrm{O}$ and $\mathrm{CO}_{2}$ are used to oxidize the redox material alternatively or together one can produce the synthesis gas $\left(\mathrm{CO}+\mathrm{H}_{2}\right)$ from totally renewable sources $\left(\mathrm{CO}_{2}\right.$ and $\left.\mathrm{H}_{2} \mathrm{O}\right)$ [30].

Sibieude et al. [10] demonstrated reduction of $\mathrm{Fe}_{3} \mathrm{O}_{4}$ to $\mathrm{FeO}$ in a solar furnace by heating the material $300{ }^{\circ} \mathrm{C}$ above its melting point. They could obtain up to $40 \%$ conversion in air and $100 \%$ conversion in argon atmosphere. Figure 2 gives the conversion rate of $\mathrm{Fe}_{3} \mathrm{O}_{4}$ to $\mathrm{FeO}$ as a function of temperature under argon flow (20 l/h).

As observed by many researchers, they also experienced that quenching the reduced oxides is very important. Table 3 summarized the $\mathrm{FeO}$ yield with various quenching rates. It can be seen that in presence of air up to $40 \%$ conversion can be obtained with $373 \mathrm{~K} / \mathrm{s}$ cooling rate.

As per literature the reduction of $\mathrm{Mn}_{3} \mathrm{O}_{4}$ to $\mathrm{MnO}$ occurs above $1,773 \mathrm{~K}$ [31]. Sibieude et al. [10] have studied reduction of $\mathrm{Mn}_{3} \mathrm{O}_{4}$ to $\mathrm{MnO}$ in a solar furnace. They could 
Table 1 Summary of potential two-step water-splitting reaction systems reported in the literature

\begin{tabular}{|c|c|c|c|c|c|}
\hline Main theme & $\begin{array}{l}T(\mathrm{~K}) \text { for } \\
\Delta G^{0}=0\end{array}$ & $\begin{array}{l}T(\mathrm{~K}) \text { for } \\
\text { reduction }\end{array}$ & $\begin{array}{l}\mathrm{H}_{2} \text { yield } \\
(\%)\end{array}$ & $\begin{array}{l}T(\mathrm{~K}) \text { for } \\
\text { oxidation }\end{array}$ & References \\
\hline $\mathrm{Fe}_{3} \mathrm{O}_{4}=3 \mathrm{FeO}+1 / 2 \mathrm{O}_{2}$ & & 2,500 & & $<1,000$ & {$[5]$} \\
\hline $2 \mathrm{Mn}_{3} \mathrm{O}_{4}=6 \mathrm{MnO}+\mathrm{O}_{2}$ & 2,000 & 1,810 & 0.002 & 900 & {$[6]$} \\
\hline $2 \mathrm{Co}_{3} \mathrm{O}_{4}=6 \mathrm{CoO}+\mathrm{O}_{2}$ & 1,000 & 1,175 & $4 \times 10^{-7}$ & 900 & [6] \\
\hline $2 \mathrm{Nb}_{2} \mathrm{O}_{5}=4 \mathrm{NbO}_{2}+\mathrm{O}_{2}$ & 4,000 & 3,600 & 99.7 & 900 & {$[6]$} \\
\hline $\mathrm{ZnO}=\mathrm{Zn}+1 / 2 \mathrm{O}_{2}$ & 2,350 & 2,300 & $\mathrm{Na}$ & $\mathrm{Na}$ & [7-9] \\
\hline $\mathrm{Mn}_{3} \mathrm{O}_{4}$ to $\mathrm{MnO}$ & $\mathrm{Na}$ & 1,773 & $\mathrm{Na}$ & $\mathrm{Na}$ & {$[10]$} \\
\hline$\left(\mathrm{Fe}_{1-x} \mathrm{M}_{x}\right)_{3} \mathrm{O}_{4}=\left(\mathrm{Fe}_{1-x} \mathrm{Mn}_{x}\right) \mathrm{O}$ & $\mathrm{Na}$ & & Very low & $773-1,173$ & {$[11,12]$} \\
\hline$\left(\mathrm{Fe}_{1-x} \mathrm{M}_{x}\right)_{3} \mathrm{O}_{4}=(\mathrm{FeM}) \mathrm{O}, \mathrm{M}=\mathrm{Ni}, \mathrm{Mn}, \mathrm{Zn}$ & $\mathrm{Na}$ & $>1,073$ & $\mathrm{Na}$ & $<1,073$ & [13] \\
\hline$\left(\mathrm{Fe}_{1-x} \mathrm{Mx}\right)_{3} \mathrm{O}_{4}=(\mathrm{FeM}) \mathrm{O}, \mathrm{M}=\mathrm{Mn}, \mathrm{Co}, \mathrm{Mg}$ & $\mathrm{Na}$ & & $\mathrm{Na}$ & $\mathrm{Na}$ & [14] \\
\hline $2 \mathrm{CdO}=2 \mathrm{Cd}+\mathrm{O}_{2}$ & $\mathrm{Na}$ & $>1,473$ & $\mathrm{Na}$ & $\mathrm{Na}$ & {$[10]$} \\
\hline $\mathrm{SnO}_{2}=\mathrm{Sn}+\mathrm{O}_{2}$ & $\mathrm{Na}$ & $>1,873$ & $90 \%$ & $773-873$ & {$[4,15]$} \\
\hline $\mathrm{ZnFe}_{2} \mathrm{O}_{4}=\mathrm{Zn}_{x} \mathrm{Fe}_{3-x} \mathrm{O}_{4}, \mathrm{Zn}(\mathrm{g}), \mathrm{O}_{2}$ & $\mathrm{Na}$ & 1,173 & & & {$[16]$} \\
\hline $\begin{array}{l}x / 3 \mathrm{Fe}_{3} \mathrm{O}_{4}+\mathrm{Y}_{y} \mathrm{Zr}_{1-y} \mathrm{O}_{2-y / 2}=\mathrm{Fe}_{x} \mathrm{Y}_{y} \mathrm{Zr}_{1-y} \mathrm{O}_{2-y / 2+x}+x / 6 \mathrm{O}_{2} \\
\mathrm{Fe}_{x} \mathrm{Y}_{y} \mathrm{Zr}_{1-y} \mathrm{O}_{2-y / 2+x}+x / 3 \mathrm{H}_{2} \mathrm{O}=x / 3 \mathrm{Fe}_{3} \mathrm{O}_{4}+\mathrm{Y}_{y} \mathrm{Zr}_{1-y} \mathrm{O}_{2-y / 2}+x / 3 \mathrm{H}_{2}\end{array}$ & $\mathrm{Na}$ & 1,673 & $\mathrm{Na}$ & $<1,273$ & {$[17,18]$} \\
\hline $2 \mathrm{CeO}_{2}(\mathrm{~s})=\mathrm{Ce}_{2} \mathrm{O}_{3}(\mathrm{~s})+1 / 2 \mathrm{O}_{2}(\mathrm{~g}) ; \mathrm{Ce}_{2} \mathrm{O}_{3}(\mathrm{~s})+\mathrm{H}_{2} \mathrm{O}(\mathrm{g})=2 \mathrm{CeO}_{2}(\mathrm{~s})+\mathrm{H}_{2}(\mathrm{~g})$ & $\mathrm{Na}$ & 2,273 & $\mathrm{Na}$ & $673-873$ & [19-21] \\
\hline $\mathrm{Ce}_{1-x} \mathrm{Zr}_{x} \mathrm{O}_{2}(0 \leq x \leq 0.3)$ & $\mathrm{Na}$ & 1,773 & $\mathrm{Na}$ & $\mathrm{Na}$ & {$[22-24]$} \\
\hline $\mathrm{TiO}_{2}=\mathrm{TiO}_{x}, x=1.83-1.96$ & $\mathrm{Na}$ & $2,573-3,073$ & $\mathrm{Na}$ & $\mathrm{Na}$ & {$[25]$} \\
\hline $\begin{array}{l}2 \mathrm{SiO}_{2}=2 \mathrm{SiO}+\mathrm{O}_{2} \\
\mathrm{SiO}(\mathrm{g})+\mathrm{H}_{2} \mathrm{O}+\mathrm{SiO}_{2}+\mathrm{H}_{2}\end{array}$ & $\mathrm{Na}$ & $3,250^{\mathrm{a}}$ & $\mathrm{Na}$ & 2,729 & {$[4,26]$} \\
\hline $\begin{array}{l}\mathrm{WO}_{3}(\mathrm{~s})=\mathrm{W}+3 / 2 \mathrm{O}_{2} \\
\mathrm{~W}+3 \mathrm{H}_{2} \mathrm{O}=\mathrm{WO}_{3}(\mathrm{~s})+3 \mathrm{H}_{2}\end{array}$ & $\mathrm{Na}$ & $4,183^{\mathrm{a}}$ & $\mathrm{Na}$ & 1,157 & {$[4,26]$} \\
\hline $\begin{array}{l}\mathrm{MoO}_{2}=\mathrm{Mo}+\mathrm{O}_{2} \\
\mathrm{Mo}+2 \mathrm{H}_{2} \mathrm{O}=\mathrm{MoO}_{2}(\mathrm{~s})+2 \mathrm{H}_{2}\end{array}$ & $\mathrm{Na}$ & $3,986^{\mathrm{a}}$ & $\mathrm{Na}$ & 1,816 & {$[4,26]$} \\
\hline $3 \mathrm{In}_{2} \mathrm{O}_{3}=\mathrm{In}_{2} \mathrm{O}_{3}+4 \mathrm{In}$ & $\mathrm{Na}$ & $>2,780^{\mathrm{a}}$ & $\mathrm{Na}$ & 1,000 & {$[4]$} \\
\hline Solid acids viz. $\mathrm{SiO}_{2}, \mathrm{Al}_{2} \mathrm{O}_{3}, \mathrm{TiO}_{2}, \mathrm{ZnO}, \mathrm{CaCO}_{3}$ & $\mathrm{Na}$ & $\mathrm{Na}$ & $\mathrm{Na}$ & $\mathrm{Na}$ & [27] \\
\hline $\mathrm{In}_{2} \mathrm{O}_{3}=\mathrm{In}_{2} \mathrm{O}+\mathrm{O}_{2} \operatorname{In}_{2} \mathrm{O}+2 \mathrm{H}_{2} \mathrm{O}=\mathrm{In}_{2} \mathrm{O}_{3}+\mathrm{H}_{2}$ & $\mathrm{Na}$ & 2,473 & $\mathrm{Na}$ & 1,073 & [28] \\
\hline $\begin{array}{c}\mathrm{MnFe}_{2} \mathrm{O}_{4}+3 \mathrm{CaO}+(1-y) \mathrm{H}_{2} \mathrm{O}=\mathrm{Ca}_{3}(\mathrm{Fe}, \mathrm{Mn})_{3} \mathrm{O}_{8-y}+(1-y) \mathrm{H}_{2} \\
\mathrm{Ca}_{3}(\mathrm{Fe}, \mathrm{Mn})_{3} \mathrm{O}_{8-y}=\mathrm{MnFe}_{2} \mathrm{O}_{4}+3 \mathrm{CaO}+(1-y) / 2 \mathrm{O}_{2}\end{array}$ & $\mathrm{Na}$ & 1,273 & $\mathrm{Na}$ & 873 & [29] \\
\hline
\end{tabular}

$\mathrm{Na}$ data not available

${ }^{\text {a }}$ Process is practically not feasible

Table 2 Approximate temperature required for which $\Delta G^{\circ}$ of the reaction (1) equals zero

\begin{tabular}{lc}
\hline Metal oxide & $T(\mathrm{~K})$ for $\Delta G^{0}=0$ \\
\hline $\mathrm{Fe}_{2} \mathrm{O}_{3}^{\mathrm{a}}$ & 3,700 \\
$\mathrm{Al}_{2} \mathrm{O}_{3}$ & $>4,000$ \\
$\mathrm{MgO}$ & 3,700 \\
$\mathrm{ZnO}$ & 2,335 \\
$\mathrm{TiO}_{2}^{\mathrm{a}}$ & $>4,000$ \\
$\mathrm{SiO}_{2}^{\mathrm{a}}$ & 4,500 \\
$\mathrm{CaO}$ & 4,400
\end{tabular}

${ }^{\mathrm{a}} \mathrm{Fe}_{2} \mathrm{O}_{3}, \mathrm{TiO}_{2}$ and $\mathrm{SiO}_{2}$ decompose to lower valence oxides before complete dissociation to the final

obtain about $80 \%$ conversion at $2,173 \mathrm{~K}$ under atmospheric pressure of air with a cooling rate of $373 \mathrm{~K} / \mathrm{s}$. The quenching of the $\mathrm{MnO}$ is very important to stop backward reaction, i.e., formation of $\mathrm{Mn}_{3} \mathrm{O}_{4}$ again. They have not performed more extensive work on this system.

Ehrensberger et al. [11] have studied non-stoichiometric FeMn oxides for two-step water-splitting reaction. They calculated $\Delta G_{\mathrm{R}}$ values for two-step Nakamura cycles FeO$\mathrm{Fe}_{3} \mathrm{O}_{4}$ and $\mathrm{MnO}-\mathrm{Mn}_{3} \mathrm{O}_{4}$ and the plotted results are shown in the Figs. 3, 4. Figure 3 indicates that $\Delta G^{0}$ equals to zero for the reduction of $\mathrm{Mn}_{3} \mathrm{O}_{4}$ to $\mathrm{MnO}$ is at least $500 \mathrm{~K}$ less than that of $\mathrm{Fe}_{3} \mathrm{O}_{4}$ to $\mathrm{FeO}$ system. However, Fig. 4 indicates that $\mathrm{FeO}$ can produce hydrogen between 873 and $1,073 \mathrm{~K}$ but $\mathrm{MnO}$ system is unable to produce hydrogen in significant levels. This led the authors to think of the possibility of combining Fe and Mn oxides to reduce spinel at lower temperature as well as produce hydrogen in significant amount in oxidation step. Authors demonstrated the oxidation of $\mathrm{Fe}_{1-y} \mathrm{O}$ and $\left(\mathrm{Fe}_{1-x} \mathrm{Mn}_{x}\right)_{1-y} \mathrm{O}(x \leq 0.3)$ in a laboratory tubular furnace and monitored gaseous 


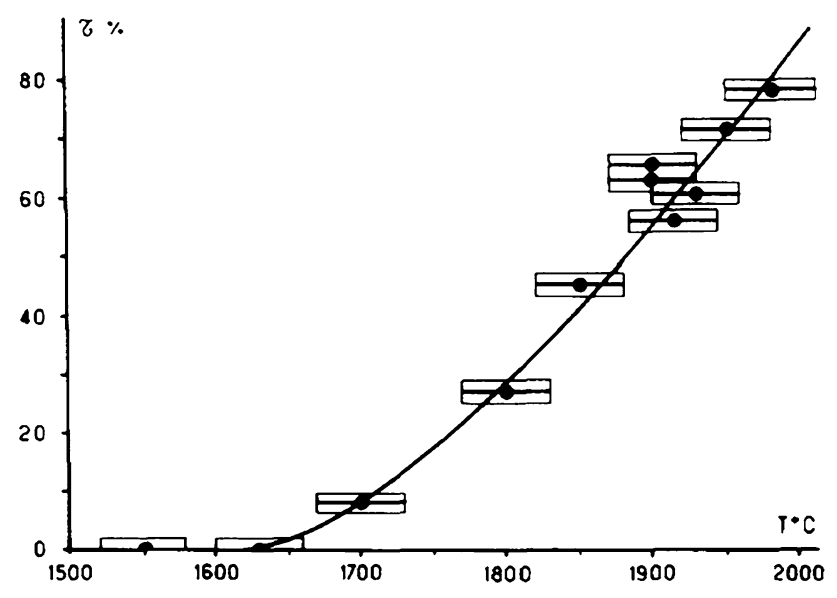

Fig. 2 Conversion rate of magnetite versus temperature

Table 3 Influence of cooling rate on $\mathrm{FeO}$ yield in air and argon atmosphere

\begin{tabular}{lcc}
\hline Atmosphere & Quenching speed $\left(\mathrm{K} \mathrm{s}^{-1}\right)$ & $\% \mathrm{~mol} \mathrm{FeO}$ \\
\hline Air $^{\mathrm{a}}$ & 278 & 0 \\
& 293 & 25 \\
& 373 & 40 \\
& 1,273 & 50 \\
Argon $^{\mathrm{a}}$ & 278 & 40 \\
& 293 & 45 \\
& 373 & 55 \\
& 1,273 & 60
\end{tabular}

${ }^{a}$ Residence time $=1 \mathrm{~min}$, temperature $=2,173 \mathrm{~K}$, flow rate $=$ $20 \mathrm{l} / \mathrm{h}$

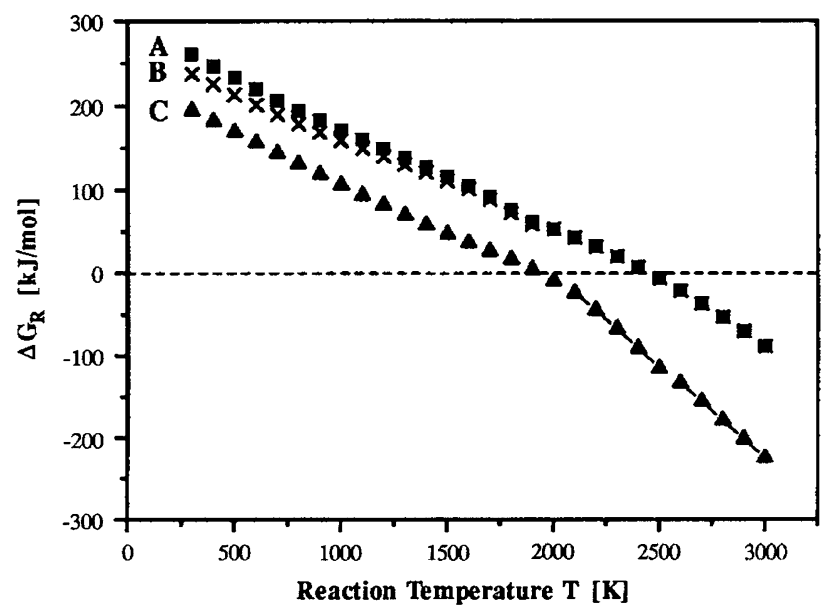

Fig. 3 Gibbs free enthalpy $\Delta G_{\mathrm{R}}$ for the decomposition of $\mathrm{Fe}_{3} \mathrm{O}_{4}(A$, $B)$ and $\mathrm{Mn}_{3} \mathrm{O}_{4}(C)$ to $\mathrm{FeO}(A), \mathrm{Fe}_{0.947} \mathrm{O}(B)$ and $\mathrm{MnO}(C)$ as a function of temperature

products using mass spectrometer. At atmospheric pressure, water with a partial pressure of about 4,200 $\mathrm{Pa}$ in nitrogen was able to oxidize $\left(\mathrm{Fe}_{1-x} \mathrm{Mn}_{x}\right)_{1-y} \mathrm{O}(x=0.0$,

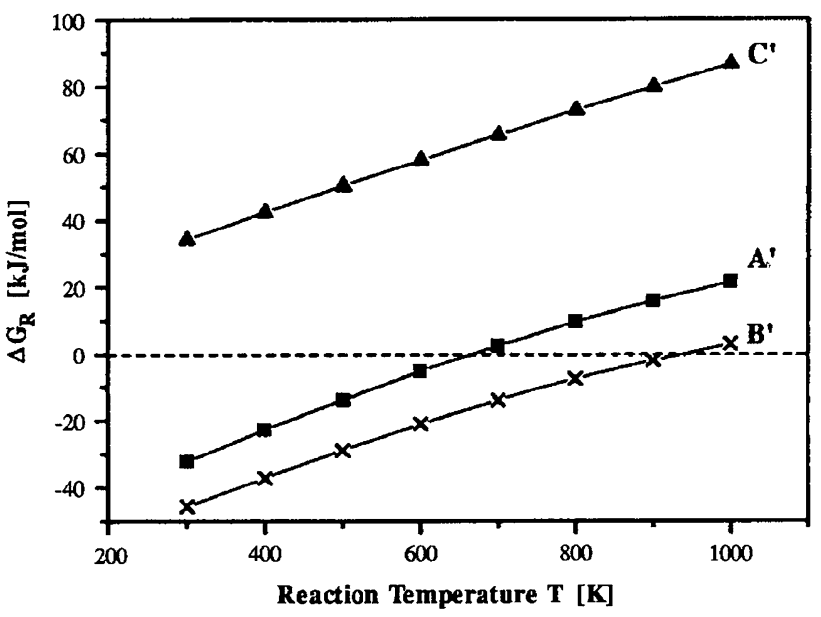

Fig. 4 Gibbs free enthalpy $\Delta G_{\mathrm{R}}$ for the water splitting reaction of $\mathrm{FeO}\left(A^{\prime}\right), \mathrm{Fe}_{0.947} \mathrm{O}\left(B^{\prime}\right)$ and $\mathrm{MnO}\left(C^{\prime}\right)$ as a function of temperature

$0.1,0.3)$ to $\left(\mathrm{Fe}_{1-x^{\prime}} \mathrm{Mn}_{x^{\prime}}\right)_{3} \mathrm{O}_{4}$ with $x^{\prime}<x$ forming molecular hydrogen. The substitution of iron with 10-30\% $\mathrm{Mn}$ in the wuestite phase did not lower the total amount of hydrogen formed, but it changed the kinetics of the process significantly. It was also found that the process is thermodynamically controlled at high temperature. The rate of water splitting decreased with increase in manganese concentration.

They also found that during water-splitting reaction $\left(\mathrm{Fe}_{1-x} \mathrm{Mn}_{x}\right)_{1-y} \mathrm{O}$ forms manganese-rich rock salt phase and an iron-rich spine phase due to phase segregation processes [12].

Tamura et al. [13] extended the work to 'NiMnFe' system, as shown in the reaction schemes 7 and 8 .

$\mathrm{Ni}_{0.5} \mathrm{Mn}_{0.5} \mathrm{Fe}_{2} \mathrm{O}_{4} \underset{\text { at }>1,073 \mathrm{~K}}{\stackrel{\text { activation }}{\longrightarrow}} \mathrm{Ni}_{0.5} \mathrm{Mn}_{0.5} \mathrm{Fe}_{2} \mathrm{O}_{4-\delta}+\frac{\delta}{2} \mathrm{O}_{2}$

$\mathrm{Ni}_{0.5} \mathrm{Mn}_{0.5} \mathrm{Fe}_{2} \mathrm{O}_{4-\delta}+\delta \mathrm{H}_{2} \mathrm{O} \underset{\text { at }<1,073 \mathrm{~K}}{\stackrel{\text { water-splitting }}{\longrightarrow}} \mathrm{Ni}_{0.5} \mathrm{Mn}_{0.5} \mathrm{Fe}_{2} \mathrm{O}_{4}+\delta \mathrm{H}_{2}$

They performed the above two-step reaction in a solar reactor at $1,073 \mathrm{~K}$. In the first endothermic step, $\mathrm{Ni}_{0.5} \mathrm{Mn}_{0.5} \mathrm{Fe}_{2} \mathrm{O}_{4}$ was thermally activated to get oxygendeficient compound, in the second step the oxygen-deficient compound was oxidized using $\mathrm{H}_{2} \mathrm{O}$ to produce $\mathrm{H}_{2}$. Since, $\mathrm{O}_{2}$ and $\mathrm{H}_{2}$ were produced in two different steps, hightemperature separation of those gases can be eliminated in the proposed method. They have demonstrated the workability of two-step water-splitting reaction with $\mathrm{NiFe}_{2} \mathrm{O}_{4}, \mathrm{Ni}_{0.5} \mathrm{Mn}_{0.5} \mathrm{Fe}_{2} \mathrm{O}_{4}$ and $\mathrm{Ni}_{0.5} \mathrm{Zn}_{0.5} \mathrm{Zn}_{2} \mathrm{O}_{4}$ systems using thermogravimetric experiments. They found that $\mathrm{NiFe}_{2} \mathrm{O}_{4}$ system needs lower reactivation rate (conducted after the water-splitting reaction) compared to 
$\mathrm{Ni}_{0.5} \mathrm{Mn}_{0.5} \mathrm{Fe}_{2} \mathrm{O}_{4}$ system. The oxygen released during reduction step in $\mathrm{NiFe}_{2} \mathrm{O}_{4}, \quad \mathrm{Ni}_{0.5} \mathrm{Mn}_{0.5} \mathrm{Fe}_{2} \mathrm{O}_{4}$ and $\mathrm{Ni}_{0.5} \mathrm{Zn}_{0.5} \mathrm{Zn}_{2} \mathrm{O}_{4}$ systems were $0.2,0.3$ and $0.4 \%$, respectively. They also demonstrated the workability of the two-step hydrogen production in solar reactors. They performed two redox cycles to prove the oxygen and hydrogen evolution in activation (reduction) and reactivation (oxidation) processes. The activation was conducted at $1,373 \mathrm{~K}$ in presence of $\mathrm{Ar}$ and reactivation was conducted in presence of (steam + Ar) flow at $573 \mathrm{~K}$. In the case of $\mathrm{ZnFe}_{2} \mathrm{O}_{4}$, reduction follows two pathways [16] as shown in Eqs. 9 and 10.

$$
\begin{aligned}
& 3 \mathrm{ZnFe}_{2} \mathrm{O}_{4}=3 \mathrm{Zn}+2 \mathrm{Fe}_{3} \mathrm{O}_{4}+2 \mathrm{O}_{2} \\
& 6 \mathrm{ZnFe}_{2} \mathrm{O}_{4}=6 \mathrm{ZnO}+4 \mathrm{Fe}_{3} \mathrm{O}_{4}+\mathrm{O}_{2}
\end{aligned}
$$

The reduction and oxidation steps have been demonstrated using $\mathrm{Xe}$ beam experiment and solar furnace experiments. It took less than $60 \mathrm{~s}$ for the $\mathrm{Zn}$ ferrite to release the expected amount of $\mathrm{O}_{2}$ from the lattice at $1,750 \mathrm{~K}$. Authors have seen deposition of $\mathrm{Zn}$ on the reactor walls during reduction step and have measured $\mathrm{O}_{2}$ released using mass spectrometer.

Abanades et al. [19] examined $\mathrm{CeO}_{2} / \mathrm{Ce}_{2} \mathrm{O}_{3}$ redox pairs and demonstrated the feasibility in a solar reactor featuring an inert gas atmosphere at $T=2,273 \mathrm{~K}, P=100-200 \mathrm{mbar}$. It consists of two chemical steps: (1) reduction, $2 \mathrm{CeO}_{2} \rightarrow$ $\mathrm{Ce}_{2} \mathrm{O}_{3}+0.5 \mathrm{O}_{2} ;$ (2) hydrolysis, $\mathrm{Ce}_{2} \mathrm{O}_{3}+\mathrm{H}_{2} \mathrm{O} \rightarrow 2 \mathrm{CeO}_{2}+$ $\mathrm{H}_{2}$. The reduction step is endothermic and takes place at $T=2,273 \mathrm{~K}, P=100-200$ mbar; however, oxidation step takes place at $673-873 \mathrm{~K}$ resulting in pure hydrogen which can be directly used in fuel cells application. The main advantages of the process are low cost material which is abundantly available in nature and the process uses noncorrosive chemicals. The reduced phase is very stable at ambient temperature and nonreactive to moisture and oxygen which makes this material ideal for on-site hydrogen generation which in turn overcomes problem associated with transportation. However, this technology has few drawbacks, a maximum heat input temperature slightly higher than $2,273 \mathrm{~K}$, the cycle working temperature of the endothermic step must be optimized to be compatible with dish or tower technologies, and to reduce sample vaporization. High molecular weight of cerium oxides poses problem in the flow of solids in the process.

Chueh et al. [20] have extended the work on $\mathrm{CeO}_{2}$ system. They demonstrated the $\mathrm{O}_{2}$ evolution during reduction step, $\mathrm{CO}$ and $\mathrm{H}_{2}$ generation during oxidation step using the solar cavity-receiver reactor over 500 cycles. They could achieve solar-to-fuel efficiencies of $0.7-0.8 \%$ and concluded that efficiency is limited by the system scale and design rather than by chemistry. However, Rager [32] pointed out that the efficiency $0.7-0.8 \%$ efficiency refers to 'peak instantaneous efficiency' but after averaging the efficiency over $80 \%$ of the fuel production, the actual efficiency is just $0.4 \%$. He recalculated the solar thermal process efficiency and found that the value is still lower than that of reported by Chueh et al. [20], mainly because the later authors did not consider the energy need for large amount of purge gas used in redox processes. Purge gas takes up lot of solar heat and hence results in lower solar thermal efficiency.

Kang et al. [23] have extended the work on $\mathrm{CeO}_{2}$ system. They synthesized $\mathrm{Ce}_{x} \mathrm{Zr}_{1-x} \mathrm{O}_{2}(x=0.6,0.7,0.8,1.0)$ solid solutions and tested for redox reactions. They found that the reduced $\mathrm{Ce}_{x} \mathrm{Zr}_{1-x} \mathrm{O}_{2-\delta}(x=0.5,0.6,0.7,0.8,1.0)$ samples exhibited higher hydrogen production ability for water splitting due to improved oxygen diffusion through the bulk. Kaneko et al. [22] have extended the work on $\mathrm{Ce}_{x} \mathrm{Zr}_{1-x} \mathrm{O}_{2-\delta}$ solid solution system. They introduced $\mathrm{Zr}^{4+}$ on various ratios in $\mathrm{CeO}_{2}$ lattices and found that the oxygen releasing capacity or extent of $\mathrm{CeO}_{2}$ reduction increases with the increase of $\mathrm{Zr}^{4+}$ ions similar to Kang et al.'s [23] observations. The highest oxygen release was found at $x=2\left(\mathrm{Ce}_{0.8} \mathrm{Zr}_{0.2} \mathrm{O}_{2}\right)$ at $1,773 \mathrm{~K}$ in air and the amount of reduced cerium was found to be about $11 \%$ which is seven times higher than just with bare $\mathrm{CeO}_{2}$. The enhancement of the $\mathrm{O}_{2}$-releasing reaction with $\mathrm{CeO}_{2}-\mathrm{ZrO}_{2}$ oxide is found to be caused by an introduction of $\mathrm{Zr}^{4+}$, which has smaller ionic radius than $\mathrm{Ce}^{3+}$ or $\mathrm{Ce}^{4+}$ in the fluorite structure.

Le Gal and Abanades [24] doped trivalent lanthanides, viz. $\mathrm{La}, \mathrm{Sm}$ and $\mathrm{Gd}$ in $\mathrm{CeO}_{2}$ to form binary oxides and used in hydrogen production by solar thermal redox cycles. They found that trivalent lanthanide-doped material improves the thermal stability of the material during consecutive redox cycles, but hydrogen production remains the same as ceria. They also doped trivalent lanthanides in $\mathrm{CeO}_{2}-\mathrm{ZrO}_{2}$ to form ternary oxides. They found that with $1 \%$ gadolinium to ceria-zirconia solid solutions nearly $338.2 \mu \mathrm{mol}$ of hydrogen per gram during one cycle with the $\mathrm{O}_{2}$-releasing step at $1,400{ }^{\circ} \mathrm{C}$ and the $\mathrm{H}_{2}$-generation step at $1,050{ }^{\circ} \mathrm{C}$. This quantity of hydrogen is more than with $\mathrm{CeO}_{2}-\mathrm{ZrO}_{2}$ system. They also found that the addition of lanthanum enhances the thermal stability of ceria-zirconia solid solution similar to as observed in cases of lanthanum-doped $\mathrm{CeO}_{2}$ binary oxides.

Lipinski et al. [21] applied first and second laws of thermodynamics to analyze the potential of applying heat recovery for realizing high efficiency in solar-driven $\mathrm{CeO}_{2}$ based non-stoichiometric redox cycles to split $\mathrm{H}_{2} \mathrm{O}$ or $\mathrm{CO}_{2}$. They found that at 2,000 K, with $80 \%$ solid phase heat recovery, advanced materials can only increase efficiency from 16 to $20 \%$, while, at $1,850 \mathrm{~K}$, advanced materials can improve efficiency from 14 to $23 \%$, a higher maximum value because of decreased re-radiation and gas heating at the lower value of $T_{\text {red }}$. 
Inoue et al. [33] demonstrated effectiveness of a $\mathrm{ZnO} /$ $\mathrm{MnFe}_{2} \mathrm{O}_{4}$ system in a lab furnace at $1,273 \mathrm{~K}$. When $\mathrm{H}_{2} \mathrm{O}$ was contacted with $\mathrm{ZnO} / \mathrm{MnFe}_{2} \mathrm{O}_{4}$ at $1,273 \mathrm{~K} \mathrm{H}_{2}$ formation happens with the expense of oxidation of $\mathrm{ZnO} /$ $\mathrm{MnFe}_{2} \mathrm{O}_{4}$. The later forms spinel kind of material containing $\mathrm{Zn}^{\mathrm{II}}, \mathrm{Mn}^{\mathrm{II}}, \mathrm{Mn}^{\mathrm{III}}$ and $\mathrm{Fe}^{\mathrm{III}}$ ions. The reaction happens by incorporation of $\mathrm{Zn}^{\mathrm{II}}$ ions into $\mathrm{MnFe}_{2} \mathrm{O}_{4}$ crystal structure, accompanied by the partial oxidation of $\mathrm{Mn}^{\mathrm{II}}$ in $\mathrm{MnFe}_{2} \mathrm{O}_{4}$ to $\mathrm{Mn}^{\mathrm{III}}$. The second step, oxygen releasing can be carried out using solar thermal route but this is not demonstrated experimentally by authors. Similarly, they have also demonstrated $\mathrm{H}_{2}$ production using $\mathrm{CaO}$ (or $\mathrm{Na}_{2} \mathrm{CO}_{3}$ ) and $\mathrm{MnFe}_{2} \mathrm{O}_{4}$ by passing steam at 1,273 $\mathrm{K}$ [29]. The mechanism of $\mathrm{H}_{2}$ formation is similar to that explained earlier, i.e., oxidation of $\mathrm{Mn}^{\mathrm{II}}$ to $\mathrm{Mn}^{\mathrm{III}}$ to form spinel kind of material $\left(\mathrm{Ca}_{3}{ }^{2+} \mathrm{Fe}_{2.02}^{3+} \mathrm{Mn}_{0.96}^{2+} \mathrm{Mn}_{0.02}^{3+} \mathrm{O}_{7.02}\right)$.

Roeb et al. [34] used monolith coatings for redox system. They noticed that the potential of the monolith coatings to absorb oxygen from steam and to release hydrogen decreased with the number of completed cycles which is due to sintering of the material which increases with the redox cycles.

Lundberg [6] performed computer model calculation for various systems for two-step solar hydrogen productions, the systems considered were $\mathrm{CoO} / \mathrm{Co}_{3} \mathrm{O}_{4}, \mathrm{MnO} / \mathrm{Mn}_{3} \mathrm{O}_{4}, \mathrm{FeO} /$ $\mathrm{Fe}_{3} \mathrm{O}_{4}, \mathrm{NbO}_{3} / \mathrm{Nb}_{2} \mathrm{O}_{5}$ and the halide systems $\mathrm{FeX}_{2} / \mathrm{Fe}_{3} \mathrm{O}_{4}$ where $X=\mathrm{F}, \mathrm{Cl}, \mathrm{Br}$ and $\mathrm{I}$. In his calculation he found that the ratio of $\mathrm{H}_{2} / \mathrm{H}_{2} \mathrm{O}$ is controlled by the temperature and oxygen partial pressure generated by the redox system. The yield of the hydrogen is defined as follows:

$Y(\%)=\frac{\mathrm{H}_{2}(\text { formed })}{\mathrm{H}_{2}(\max )} \times 100$

where $\mathrm{H}_{2}$ max is the maximum amount of hydrogen that can be formed as per the formula:

$\mathrm{MO}($ red $)+\mathrm{H}_{2} \mathrm{O}(\mathrm{g})=\mathrm{MO}(\mathrm{ox})+\mathrm{H}_{2}(\mathrm{~g})$.

Calculations showed that $\mathrm{FeO}-\mathrm{Fe}_{3} \mathrm{O}_{4}$ and $\mathrm{NbO}_{2}-\mathrm{Nb}_{2} \mathrm{O}_{5}$ systems give more $\mathrm{H}_{2}$ yield at lower temperature and that of $\mathrm{MnO}-\mathrm{Mn}_{3} \mathrm{O}_{4}$ and $\mathrm{CoO}-\mathrm{Co}_{3} \mathrm{O}_{4}$ systems give $>1 \% \mathrm{H}_{2}$ yield at any temperature. In reduction step, in order to reduce thermally oxidized metal oxide needs to be heated up to a temperature where its oxygen partial pressure is higher than in atmosphere $(0.21 \mathrm{~atm})$. It was found that though $\mathrm{FeO}-\mathrm{Fe}_{3} \mathrm{O}_{4}$ and $\mathrm{NbO}_{2}-\mathrm{Nb}_{2} \mathrm{O}_{5}$ give higher yield they need to be heated above their melting point to reduce them. On the other hand, $\mathrm{MnO}-\mathrm{Mn}_{3} \mathrm{O}_{4}$ and $\mathrm{CoO}-\mathrm{Co}_{3} \mathrm{O}_{4}$ systems can be reduced below their melting point but hydrogen yield in these systems are very low (Table 4). Therefore, none of the systems studied are suitable to fulfill both desired conditions for the redox reactions.

It was also tried to combine metal oxide which yields higher $\mathrm{H}_{2}$ with metal oxide which can be reduced below its melting point to find out whether this fulfills the need of redox cycle. Considering the spinel phase composition of $\left(\mathrm{Fe}_{0.85} \mathrm{Co}_{0.15}\right)_{3} \mathrm{O}_{4}$ the $\mathrm{H}_{2}$ yield obtained was $45 \%$, but during the oxidation of the $\left(\mathrm{Fe}_{0.85} \mathrm{Co}_{0.15}\right) \mathrm{O}$ system the equilibrium oxygen pressure of the redox system will successfully increases and the yield of the $\mathrm{H}_{2}$ will gradually decreases down to about $3 \%$. The opposite effect was found during the reduction step, the spinel phase with composition $\left(\mathrm{Fe}_{0.85} \mathrm{Co}_{0.15}\right)_{3} \mathrm{O}_{4}$ will start to be reduced at $2,020 \mathrm{~K}$, but while reduction of the spinel the wuestite phase will become rich with iron and the oxygen partial pressure will decrease leading to gradual increase in the reduction temperature of $2,135 \mathrm{~K}$ by the time the initial composition is reached.

An yttrium-stabilized cubic zirconia material coated with iron oxide was proposed to split water in the temperature range 1,273-1,673 $\mathrm{K}$ [35, 36]. Kodam et al. [17] studied supported $\mathrm{Fe}_{3} \mathrm{O}_{4}-\mathrm{FeO}$ system. Various amount of iron oxide was supported on yttrium-supported $\mathrm{ZrO}_{2}$ for cyclic redox study. It was found that the $\mathrm{Fe}_{3} \mathrm{O}_{4}$ reacts with YSZ to produce $\mathrm{Fe}^{2+}$-containing $\mathrm{ZrO}_{2}$ phase by releasing oxygen molecules in the first step. It was also found that the $\mathrm{Fe}^{2+}$ ions enters into the cubic YSZ lattice. In the second step, the $\mathrm{Fe}^{2+}$-containing YSZ generated hydrogen via steam splitting to reproduce $\mathrm{Fe}_{3} \mathrm{O}_{4}$ on the cubic YSZ support. The system showed good reproducibility. It was found that when the $\mathrm{Fe}_{3} \mathrm{O}_{4}$ content was increased up to $30 \mathrm{wt} \%$ on the $\mathrm{Fe}_{3} \mathrm{O}_{4} / \mathrm{YSZ}$ sample [17], the sample became denser and harder mass after the thermal reduction step, similar to the unsupported $\mathrm{Fe}_{3} \mathrm{O}_{4}$. This is due to the fact that the limitation of $\mathrm{Fe}^{2+}$ solubility in the YSZ exists close
Table 4 The yield of $\mathrm{H}_{2}$ at $900 \mathrm{~K}$ for the different metal oxide systems together with the enthalpy of the reaction, the reduction temperature in air and the melting points of the system

\begin{tabular}{|c|c|c|c|c|c|}
\hline \multirow[t]{2}{*}{ System } & \multirow{2}{*}{$\begin{array}{l}\text { Yield } \mathrm{H}_{2} \text { at } \\
900 \mathrm{~K}(\%)\end{array}$} & \multirow{2}{*}{$\begin{array}{l}\Delta H_{\mathrm{r}} / \mathrm{H}_{2} \text { at } \\
900 \mathrm{~K}(\mathrm{~kJ})\end{array}$} & \multirow{2}{*}{$\begin{array}{l}\text { Reduction } \\
\text { temperature } \\
\text { in air }\end{array}$} & \multicolumn{2}{|c|}{ Melting point $(\mathrm{K})$} \\
\hline & & & & Reduced phase & Oxidized phase \\
\hline $\mathrm{NbO}_{2} / \mathrm{Nb}_{2} \mathrm{O}_{5}$ & 99.7 & -62.7 & 3,600 & 2,175 & 1,785 \\
\hline $\mathrm{FeO} / \mathrm{Fe}_{3} \mathrm{O}_{4}$ & 63 & -49.5 & 2,685 & 1,650 & 1,870 \\
\hline $\mathrm{MnO} / \mathrm{Mn}_{3} \mathrm{O}_{4}$ & 0.002 & 17 & 1,810 & 2,115 & 1,835 \\
\hline $\mathrm{CoO} / \mathrm{Co}_{3} \mathrm{O}_{4}$ & $4 \times 10^{-7}$ & 251.2 & 1,175 & 2,080 & Decomposes at 1,175 \\
\hline
\end{tabular}


to the $25 \mathrm{wt} \% \mathrm{Fe}_{3} \mathrm{O}_{4}$ content in the $\mathrm{Fe}_{3} \mathrm{O}_{4} / \mathrm{YSZ}$. When raising the $\mathrm{Fe}_{3} \mathrm{O}_{4}$ content above $25 \mathrm{wt} \%$, excess $\mathrm{Fe}^{2+}$ ions would form $\mathrm{FeO}$ crystals on the $\mathrm{ZrO}_{2}$ surface, which in turn melts at $1,713 \mathrm{~K}$. Therefore, the $\mathrm{Fe}_{3} \mathrm{O}_{4}$ contents should be limited to $<25 \%$ to avoid sintering of redox material and its cyclic reproducibility.

The disadvantage of mixed iron oxide cycles where oxides are partially reduced and oxidized is their low molar ratio of released oxygen to the total oxygen present in the system. The major drawback of all systems using reactive coatings is their low ratio of hydrogen mass generated to support structure mass. Considering the properties of the above problems, the cycle based on the $\mathrm{ZnO} / \mathrm{Zn}$ redox pair [7-9] is of special interest since no cyclic heating and cooling is required and a pure metal state is achieved. It consists of the solar endothermal dissociation of $\mathrm{ZnO}(\mathrm{s})$ into its elements; and the non-solar exothermal steamhydrolysis of $\mathrm{Zn}$ into $\mathrm{H}_{2}$ and $\mathrm{ZnO}(\mathrm{s})$, and represented by Eqs. 13 and 15.

1st step (solar $\mathrm{ZnO}$-decomposition) $\mathrm{ZnO} \rightarrow \mathrm{Zn}+0.5 \mathrm{O}_{2}$

2nd step (non-solar Zn-hydrolysis): $\mathrm{Zn}+\mathrm{H}_{2} \mathrm{O}$

$\rightarrow \mathrm{ZnO}+\mathrm{H}_{2}$

$\mathrm{H}_{2}$ and $\mathrm{O}_{2}$ are derived in different steps, thereby eliminating the need for high-temperature gas separation. This cycle has been proposed to be a promising route for solar $\mathrm{H}_{2}$ production from $\mathrm{H}_{2} \mathrm{O}$ because of its potential of reaching high-energy conversion efficiencies and thereby its economic competitiveness [37, 38].

The first step of the two-step $\mathrm{ZnO} / \mathrm{Zn}$ water-splitting cycle was first demonstrated in a solar furnace in 1977 by Bilgen et al. [4]. They have demonstrated the decomposition of $\mathrm{ZnO}$ in a solar furnace. They also found that $\mathrm{Zn}$ yield increases if $\mathrm{ZnO}$ is diluted with other refractory materials like $\mathrm{ZrO}_{2}$ and $\mathrm{Y}_{2} \mathrm{O}_{3}$ and if the reaction is carried out in the presence of argon inert gas. Table 5 summarized the $\mathrm{Zn}$ yield found in the different experiments and different conditions.

Recently, the solar thermal $\mathrm{ZnO}$ dissociation was demonstrated by Lédé et al. [39] in a quartz vessel containing sintered $\mathrm{ZnO}$, by Haueter et al. [40] in a rotating cavity reactor type, and by Perkins et al. [41] in an aerosol reactor type. Perkins et al. reported the $\mathrm{O}_{2}$ measurement, which is the only clear indicator of the ongoing thermal $\mathrm{ZnO}$ dissociation. The maximum net $\mathrm{Zn}$ yield was $17 \%$ [41]. However, to-date there is no report in the literature which claims continuous dissociation of $\mathrm{ZnO}$ monitored by product gas analysis for more than few minutes.

Palumbo et al. [25] have studied $\mathrm{TiO}_{2}$ system for twostep solar production of $\mathrm{Zn}$ from $\mathrm{ZnO}$, the primary reaction schemes can be written as shown in reactions (15) and (16).

$$
\begin{aligned}
& \mathrm{TiO}_{2}(\mathrm{l})=\mathrm{TiO}(\mathrm{l})+(1-x / 2) \mathrm{O}_{2} \quad T \geq 2,300 \mathrm{~K} \\
& \mathrm{TiO}_{x}(\mathrm{~s}, \mathrm{l})+(2-x) \mathrm{ZnO}(\mathrm{s})=(2-x) \mathrm{Zn}(\mathrm{g})+\mathrm{TiO}_{2}(\mathrm{~s}) \\
& \quad T>1,200 \mathrm{~K}
\end{aligned}
$$

But the authors have not tried water splitting using partially reduced $\mathrm{TiO}_{x}$. The minimum values of $x$ that the authors obtained experimentally were $1.91,1.86$ and 1.83 for temperatures of 2,300, 2,500, and 2,700 K, respectively, in an Ar atmosphere at 1 bar. They used the latter material to reduce $\mathrm{ZnO}$ to produce $\mathrm{Zn}$ as indicated in reaction (16). It is to be noted that the higher the degree of decomposition, the greater the vaporization of $\mathrm{TiO}_{2}$, this limits the efficiency of the water-splitting cycle using $\mathrm{TiO}_{2}$ system.

Sibieude et al. [10] have used $\mathrm{CdO}$ for two-step watersplitting reaction. They demonstrated reduction of $\mathrm{CdO}$ to $\mathrm{Cd}$ in a solar furnace at high temperature. The reaction scheme is shown in Eqs. 17-19.

\begin{tabular}{|c|c|c|c|c|c|c|c|c|}
\hline & \multicolumn{2}{|l|}{ Air $p$ (bar) } & \multicolumn{5}{|c|}{ Argon atmosphere $p$ (bar) } & \\
\hline & $<0.001$ & 1 & $<0.001$ & 0.034 & 0.092 & 0.263 & 0.789 & \\
\hline $\mathrm{ZnO}$ & $\begin{array}{l}\text { Between } 20 \text { and } \\
30 \mathrm{~mol} \% \text { of } \mathrm{Zn}\end{array}$ & No $\mathrm{Zn}$ formation & $\begin{array}{r}\text { Difficult } \\
\text { sample } \\
68 \text { mol\% } \\
45 \text { mol\% }\end{array}$ & $\begin{array}{l}\text { ist in o } \\
\text { results } \\
\text { obtaine } \\
\text { obtaine }\end{array}$ & $\begin{array}{l}\text { ng due } t \\
\text { orly rep } \\
p<0.0 \\
p=0.2\end{array}$ & $\begin{array}{l}\text { ng vola } \\
\text { ible } \\
\text { Ar } \\
\text { r Ar (in }\end{array}$ & $\begin{array}{l}\text { ion of } \mathrm{ZnO} \\
\text { w of gas) }\end{array}$ & Static atmosphere \\
\hline $10 \mathrm{~mol} \% \mathrm{ZnO}$ & & & & $70 \%$ & $62 \%$ & $60 \%$ & $25 \%$ & Static atmosphere \\
\hline $90 \mathrm{~mol} \% \mathrm{Y}_{2} \mathrm{O}_{3}$ & & & $71 \%$ & $76 \%$ & $66 \%$ & $68 \%$ & $65 \%$ & Gas circulation \\
\hline $10 \mathrm{~mol} \% \mathrm{ZnO}$ & & & & $67 \%$ & $60 \%$ & $60 \%$ & $30 \%$ & Static atmosphere \\
\hline $90 \mathrm{~mol} \% \mathrm{ZrO}_{2}$ & & & $75 \%$ & $74 \%$ & $65 \%$ & $70 \%$ & $67 \%$ & Gas circulation \\
\hline
\end{tabular}

Table $5 \mathrm{Mol} \%$ zinc content of condensed vapors from $\mathrm{ZnO}$ and mixed oxides $\mathrm{ZnO}-\mathrm{Y}_{2} \mathrm{O}_{3}, \mathrm{ZnO}-\mathrm{ZrO}_{2}$ samples heated at the focus of $2 \mathrm{~kW}$ solar concentrator 


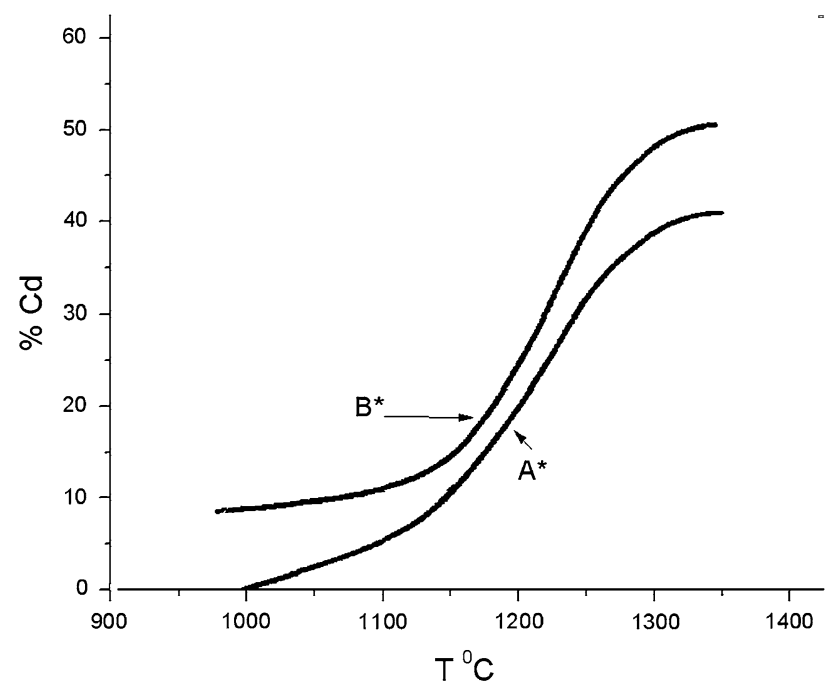

Fig. $5 \mathrm{Cd}$ (metal) content of condensates versus temperature after thermal decomposition of $\mathrm{CdO}$, flow rate of argon was $A^{*} 3.4 \mathrm{~cm}^{3} / \mathrm{s}$ and $B^{*} 10 \mathrm{~cm}^{3} / \mathrm{s}$

$$
\begin{aligned}
& \mathrm{CdO} \rightarrow \mathrm{Cd}+1 / 2 \mathrm{O}_{2} \quad T>1,200{ }^{\circ} \mathrm{C} \\
& \mathrm{Cd}+\mathrm{H}_{2} \mathrm{O} \rightarrow \mathrm{Cd}(\mathrm{OH})_{2}+\mathrm{H}_{2} \\
& \mathrm{Cd}(\mathrm{OH})_{2} \rightarrow \mathrm{CdO}+\mathrm{H}_{2} \mathrm{O} \quad T>375^{\circ} \mathrm{C}
\end{aligned}
$$

They observed that subjecting $\mathrm{CdO}$ alone to solar radiation did not reduce the oxide, but when $\mathrm{CdO}$ was mixed with refractory material, in their case $20 \% \mathrm{~mol}$ $\mathrm{ZrO}_{2}$, resulted in the formation of $\mathrm{Cd}$ metal in the stream of Ar. The amount of $\mathrm{Cd}$ metal in the deposited condensate at different temperatures is shown in Fig. 5.

Quenching of evaporated metal was very important in this reaction. When $\mathrm{CdO}$ was dissociated into $\mathrm{Cd}(\mathrm{g})$ and $\mathrm{O}(\mathrm{g})$ the recombination will also takes place very fast.

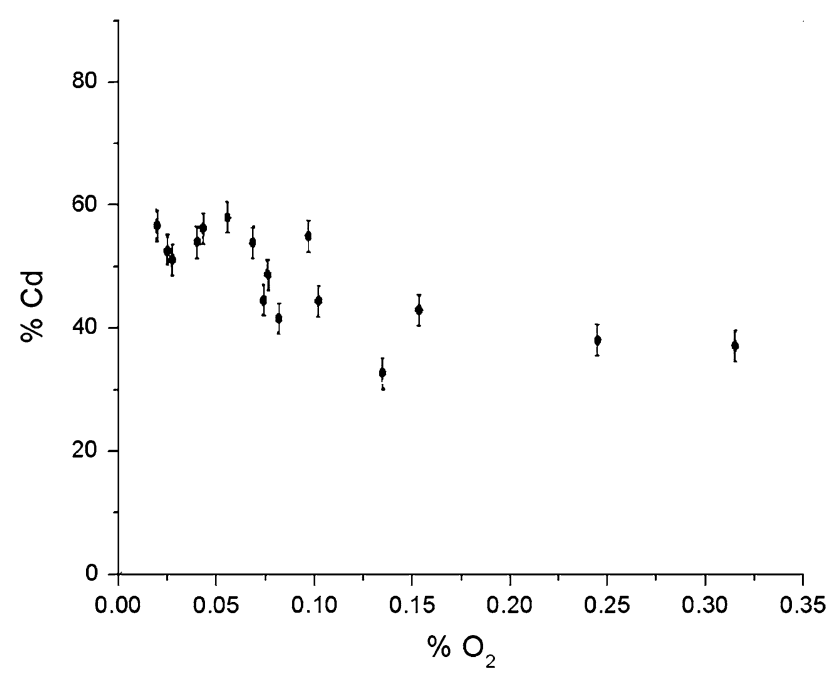

Fig. 6 Dependence of $\mathrm{Cd}$ (metal) content of condensates on the oxygen concentration of the argon flow
When $\mathrm{CdO}$ alone was heated strong vaporization produces large amount of dissociated vapors which is insufficiently quenched by the argon flow on a water cooled wall of the condenser. The problem was overcome by mixing the $\mathrm{CdO}$ with $\mathrm{ZrO}_{2}$; in this case vaporization rate of $\mathrm{Cd}$ metal was lowered by its dispersion in the refractory metal oxide matrix which permits the effective quenching of vaporized metal. It is to be noted that partial pressure of oxygen plays a main role in the $\mathrm{Cd}$ yield. Figure 6 gives the $\% \mathrm{Cd}$ metal recovered in various $\mathrm{O}_{2}$ partial pressures.

Abanades et al. [15] have studied $\mathrm{SnO}_{2}=\mathrm{Sn}+1 / 2 \mathrm{O}_{2}$ cycle which consists of a solar endothermic reduction of $\mathrm{SnO}_{2}$ into $\mathrm{SnO}(\mathrm{g})$ and $\mathrm{O}_{2}$ followed by a non-solar exothermic hydrolysis of $\mathrm{SnO}(\mathrm{s})$ to form $\mathrm{H}_{2}$ and $\mathrm{SnO}_{2}(\mathrm{~s})$. The thermal reduction occurs under atmospheric pressure at about $1,873 \mathrm{~K}$ and over. The solar step encompasses the formation of $\mathrm{SnO}$ nanoparticles that can be hydrolyzed efficiently in the temperature range of $500-600{ }^{\circ} \mathrm{C}$ with a $\mathrm{H}_{2}$ yield over $90 \%$. A preliminary process design is also proposed for cycle integration in solar chemical plants. They also compared their system with literature reported 'Sn-Souriau' [42] three-step cycles and inferred that the reaction (22) producing hydrogen from the $\mathrm{Sn} / \mathrm{SnO}_{2}$ mixture produced from reaction (21) is slow and partial at $600{ }^{\circ} \mathrm{C}$ which results in low $\mathrm{H}_{2}$ yield of $<45 \%$. The threestep cycling process proposed by them is as follows:

$\mathrm{SnO}_{2} \rightarrow \mathrm{SnO}+1 / 2 \mathrm{O}_{2}$

$2 \mathrm{SnO} \rightarrow \mathrm{Sn}+\mathrm{SnO}_{2}$

$\mathrm{Sn}+2 \mathrm{H}_{2} \mathrm{O} \rightarrow \mathrm{SnO}_{2}+\mathrm{H}_{2}$

Fan et al. [43] have studied steam to hydrogen conversion using six different metals. It is interesting to note that only $\mathrm{Fe}$ and $\mathrm{Sn}$ are found to generate reasonable hydrogen at $873 \mathrm{~K}$ as shown in Table 6. Other metals did not show a good amount of hydrogen production at $873 \mathrm{~K}$. Considering melting point of different metallic and their oxides states (as shown in Table 7) of Fe and $\mathrm{Sn}$ it can be inferred that $\mathrm{Fe}$ is very suitable for given application unless there is a provision to handle liquid metal in the solar reactor similar to $\mathrm{Zn}-\mathrm{ZnO}_{2}$ case. The steam to $\mathrm{H}_{2}$ value $\left(\gamma^{a}\right)$ of $40.82 \%$ is lower compared to one reported by Abanades et al. [15] which is equivalent to $90 \%$ at similar conditions. If solar reactor is designed to handle liquid metals, then both $\mathrm{Zn}$ and $\mathrm{Sn}$ seems to be better candidates for two-step redox reactions with good hydrogen yield and at low-temperature operation.

Recently, Cho and Kim [27] reported production of $\mathrm{H}_{2}$ using solid acids such as silica gel, activated $\mathrm{Al}_{2} \mathrm{O}_{3}$, $\mathrm{CaCO}_{3}, \mathrm{TiO}_{2}$ and $\mathrm{ZnO}$. This is very interesting study as it reports on liberation of hydrogen gas at very low temperature. They have demonstrated the possibility of $\mathrm{H}_{2}$ production using a laboratory plug flow reactor. Figure 7 gives 
Table 6 Maximum per-pass conversion of $\mathrm{H}_{2} \mathrm{O}$ to $\mathrm{H}_{2}$ in the regeneration reactor and the stable phase obtained at $873 \mathrm{~K}$ for countercurrent gas-solid operation

\begin{tabular}{lcl}
\hline Metal phase & $\gamma^{a}(\%)$ & Oxidized phase \\
\hline $\mathrm{Ni}$ & 0.4 & $\mathrm{NiO}$ \\
$\mathrm{Cd}$ & 1.83 & $\mathrm{CdO}$ \\
$\mathrm{Cu}$ & 0 & $\mathrm{Cu}_{2} \mathrm{O}$ \\
$\mathrm{Co}$ & 2.27 & $\mathrm{CoO}$ \\
$\mathrm{Sn}$ & 40.82 & $\mathrm{SnO}_{2}$ \\
$\mathrm{MnO}$ & 0 & $\mathrm{Mn}_{3} \mathrm{O}_{4}$ \\
$\mathrm{Fe}$ & 74.79 & $\mathrm{Fe}_{3} \mathrm{O}_{4}$ \\
$\mathrm{Fe}$ & 74.79 & $\mathrm{Fe}_{2} \mathrm{O}_{3}$ \\
\hline
\end{tabular}

$\gamma^{a}$ conversion of $\mathrm{H}_{2} \mathrm{O}$ to $\mathrm{H}_{2}$

Table 7 Melting points [44] of various phases of Fe and Sn

\begin{tabular}{lc}
\hline Material & Melting point $(\mathrm{K})$ \\
\hline $\mathrm{Fe}$ (cast) & 1,548 \\
$\mathrm{Fe}$ (pure) & 1,808 \\
$\mathrm{FeO}$ & 1,693 \\
$\mathrm{Fe}_{3} \mathrm{O}_{4}$ & 1,538 \\
$\mathrm{Fe}_{2} \mathrm{O}_{3}$ & 1,811 \\
$\mathrm{Sn}$ & 504 \\
$\mathrm{SnO}$ & 1,353 \\
$\mathrm{SnO}_{2}$ & 1,400 \\
\hline
\end{tabular}

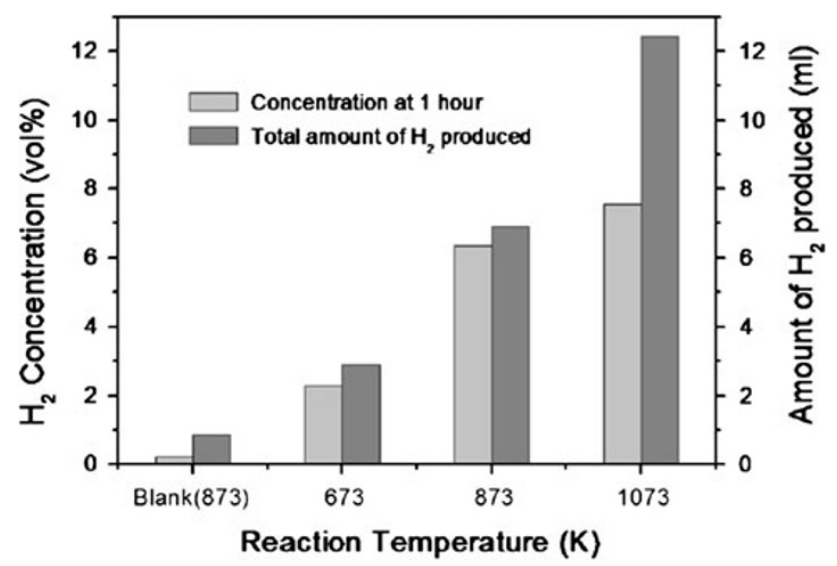

Fig. $7 \mathrm{H}_{2}$ concentration in the product gas stream at a reaction time of $1 \mathrm{~h}$ and total amount of $\mathrm{H}_{2}$ produced versus reaction temperature resulted from using a wetted $\mathrm{Al}_{2} \mathrm{O}_{3}$. For the experiments, $60 \mathrm{~g}$ of $\mathrm{Al}_{2} \mathrm{O}_{3}\left(5.5 \mathrm{wt} \% \mathrm{H}_{2} \mathrm{O}\right)$ in a stainless steel reactor and $2 \mathrm{ml} / \mathrm{min}$ of $\mathrm{CO}_{2}$ carrier gas were used at atmospheric pressure

the concentration and total amount of $\mathrm{H}_{2}$ liberated at various temperatures using activated $\mathrm{Al}_{2} \mathrm{O}_{3}$.

The concentration of hydrogen produced in product gas stream using five different oxides at $\approx 610 \mathrm{~K}$ is shown in the Table 8. Though $\mathrm{CaCO}_{3}$ shows highest concentration of $\mathrm{H}_{2}$, i.e., $1,590 \mathrm{ppm}$ in $1 \mathrm{~h}$ reaction time the activated $\mathrm{Al}_{2} \mathrm{O}_{3}$ produces highest amount of total $\mathrm{H}_{2}$ at $1,073 \mathrm{~K}$.

Though the authors demonstrated the workability of the producing hydrogen from solid acids on a laboratory-scale fixed-bed reactor, replication of the results in a solar reactor needs to be performed to know the feasibility of the process.

One of the main problem to tackle is overcoming sintering of redox material. Agglomeration due to sintering brings down the recyclability over multiple redox cycles. The key properties of the redox material should include a high oxygen carrying capacity, good mechanical properties and cheap and easy synthetic procedures. If redox material do not fulfill any one of these key properties it would not be a suitable material for commercial-scale operation.

Particle size or grain size effect on rate of oxidation

It is generally accepted that smaller the particle size easier is to oxidize or reduce. In case of two-phase alloys the rate of oxidation may significantly improve with grain size reduction because both mutual solubility and diffusivity among the system will enhance $[45,46]$. But this is not always the case, during the oxidation if the top layer acts as a protective layer then the further oxidation of the metals will be hampered.

Figure 8 shows the oxidation kinetics of three different alloy systems with two different grain sizes at 1,073 K. The grain size reduced $\mathrm{Cu}-\mathrm{Cr}$ alloy showed very slow oxidation kinetics compared to As-cast alloy. But in case of $\mathrm{Cu}-\mathrm{Fe}$ and $\mathrm{Cu}-\mathrm{Co}$ oxidation kinetics found to be much faster when nano-crystals $(20-30 \mathrm{~nm})$ were used compared to the As-cast alloy. This is because $\mathrm{Cr}_{2} \mathrm{O}_{3}$ scale formed on alloy prevents further oxidation. This is similar to in case aluminum where external layer forms $\mathrm{Al}_{2} \mathrm{O}_{3}$ and prevents further oxidation or corrosion of the aluminum metal.

The reduction kinetics of metal oxides depends on many factors such as whether they are supported or unsupported, particle size, gas atmosphere, kind of metal oxides and whether single or mixed metal oxides. There are not many reports available on high-temperature reduction of metal oxides in an inert atmosphere as in the case of solar thermal reduction, but there are plenty of studies available in the literature on reduction of metal oxides using $\mathrm{H}_{2}$ or $\mathrm{CO}$ as reducing agents. For example, Syed-Hassan and Chun-Zhu [47] have studied the particle size effect on reduction of $\mathrm{NiO}$ in $\mathrm{H}_{2}$ atmosphere. The reduction profiles for $\mathrm{NiO}$ particles of size 20 and $24 \mathrm{~nm}$ are very different from that of particle size of $3.3 \mathrm{~nm}$ (please refer Fig. 5a in Ref. [47]). The profiles for 20 and $24 \mathrm{~nm}$ are almost similar and very much resemble to that of $55 \mathrm{~nm} \mathrm{NiO}$ supported on $\mathrm{SiO}_{2}$ substrate. Authors concluded that reduction kinetics is independent of supported or unsupported $\mathrm{NiO}$, but merely 
Table $8 \mathrm{H}_{2}$ concentration in the product gas stream at a reaction time of $1 \mathrm{~h}$

\begin{tabular}{|c|c|c|c|c|c|c|c|c|c|c|}
\hline \multirow{2}{*}{$\frac{\text { Solid acid (amount) }}{\mathrm{H}_{2} \mathrm{O}(\mathrm{wt} \%)}$} & \multicolumn{2}{|c|}{$\mathrm{Al}_{2} \mathrm{O}_{3}(50 \mathrm{~g})$} & \multicolumn{2}{|c|}{$\mathrm{SiO}_{2}(30 \mathrm{~g})$} & \multicolumn{2}{|c|}{$\mathrm{TiO}_{2}(50 \mathrm{~g})$} & \multicolumn{2}{|c|}{$\mathrm{ZnO}(50 \mathrm{~g})$} & \multicolumn{2}{|c|}{$\mathrm{CaCO}_{3}(50 \mathrm{~g})$} \\
\hline & 0 & 5.2 & 0 & 5.3 & 0 & 5.1 & 0 & 5.1 & 0 & 5.0 \\
\hline $\mathrm{H}_{2}(\mathrm{ppm})$ & 0 & 870 & 0 & 200 & 0 & 260 & 0 & 630 & 0 & 1,590 \\
\hline
\end{tabular}

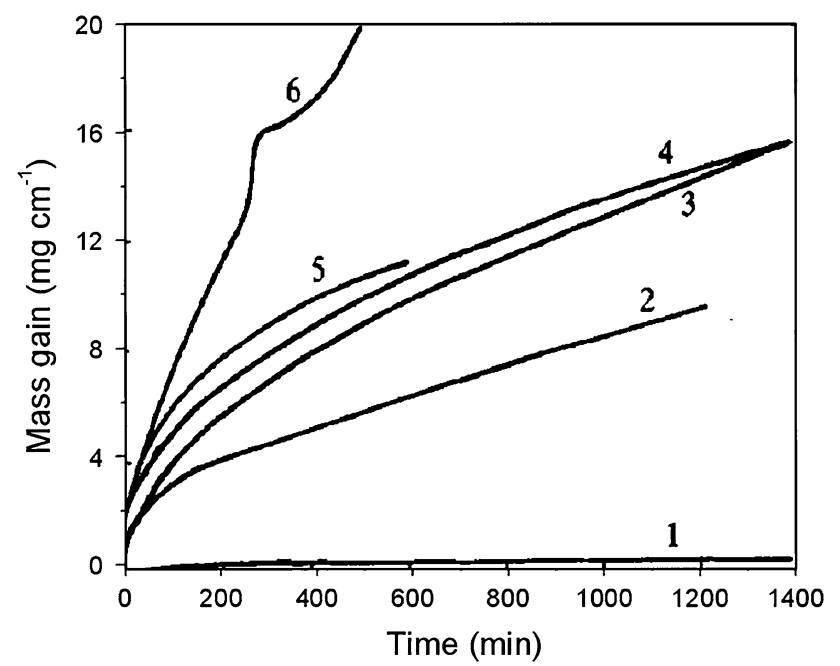

Fig. 8 Oxidation kinetics of As-cast and grain size reduced $\mathrm{Cu}-\mathrm{M}$ alloys at 1,073 K. 1 Grain size reduced $\mathrm{Cu}-\mathrm{Cr}$ alloy, $2 \mathrm{As}$-cast $\mathrm{Cu}-\mathrm{Co}$ alloy, 3 As-cast $\mathrm{Cu}-\mathrm{Cr}$ alloy, 4 grain size reduced $\mathrm{Cu}-\mathrm{Fe}$ alloy, 4 Ascast $\mathrm{Cu}-\mathrm{Fe}$ alloy, 6 grain size reduced $\mathrm{Cu}-\mathrm{Co}$ alloy. [45]

depends on the particle/crystal size. The $E_{\mathrm{a}}$ versus $\% \mathrm{NiO}$ converted trends are very different for first reduction (particle size $3.3 \mathrm{~nm}$ ) to that of second (particle size $=20 \mathrm{~nm}$ ) and third reduction (particle size $=24 \mathrm{~nm}$ ) (please refer Fig. 5b in Ref. [47]). The $E_{\mathrm{a}}$ for first reduction remains almost unchanged (indicating single rate-limiting step) throughout the whole reduction process, but for second and third reduction steps the $E_{\text {a }}$ profiles continuously increased till the complete reduction of $\mathrm{NiO}$. The main reason for the difference could be due to the difference in surface to bulk atoms in different particle size crystals. The size of the metallic island which forms during initial stages of reduction is bigger than particle size, i.e., $3.3 \mathrm{~nm}$, or the whole particle surface can be instantaneously covered by the metallic layer without requiring a significant growth of islands; therefore, the reduction happens immediately in those particles size crystals. But for a big particle with significant atoms in the interior (e.g., $20 \mathrm{~nm}$ ) it might take quite some time for the growth of island to cover the whole particle's surface. Once the surface has been covered completely by the metal product, the $\mathrm{Ni}-\mathrm{NiO}$ boundary would then progressively advance inward. As reduction continues, the hydrogen radicals moves towards $\mathrm{Ni}-\mathrm{NiO}$ boundary on the surface and the diffusion of atoms (i.e., movement and rearrangements of atoms in the interior of
Table 9 Hydrogen cost estimation (per $\mathrm{kg} \mathrm{H}_{2}$ ) in different processes

\begin{tabular}{lllllllll}
\hline Years & $\mathrm{Hy}-\mathrm{S}$ & $\mathrm{CuCl}$ & Ferrite & $\mathrm{S}-\mathrm{A}$ & $\mathrm{ZnO}$ & $\mathrm{CdO}$ & $\mathrm{MnO}$ & $\mathrm{S}-\mathrm{I}$ \\
\hline 2015 & $\$ 5.68$ & $\$ 6.83$ & $\$ 4.06$ & $\$ 7.78$ & $\$ 6.07$ & $\mathrm{NA}$ & $\$$ & $\$$ \\
2025 & $\$ 3.85$ & $\$ 5.39$ & $\$ 2.42$ & $\$ 4.71$ & $\$ 4.18$ & $\mathrm{NA}$ & $\$ 4.63$ & $\$ 4.68$
\end{tabular}

the particle) takes place. In general, solid-state diffusion requires higher activation energy [48]. The number of steps of diffusion in the solid state would appear to increase with $\mathrm{NiO}$ conversion, resulting in continuous increases in the activation energy. This is the reason in general the reduction of bigger particles crystallites needs higher activation energy than smaller one.

\section{Economic evaluation}

The US DOE has established a target of $\$ 2$ to $\$ 3$ per $\mathrm{kg}$ hydrogen by 2025 to make it economically affordable. The short term, i.e., 2015, DOE target is $\$ 6 / \mathrm{kg}$ hydrogen. Any competitive technology to produce hydrogen considers this figure as a reference for their process efficiency and economic evaluation.

DOE in collaboration with TIAX (TIAX is a laboratorybased technology development company with a focus on clean energy) led the effort of cost calculation for solar thermochemical hydrogen (STCH) in many US national laboratories. They considered eight promising technologies for cost calculations, viz., hybrid-sulfur (HyS), copper chloride $(\mathrm{CuCl})$, thin-film nickel ferrite ("ferrite"), sulfurammonia ( $\mathrm{S}-\mathrm{A})$, zinc oxide $(\mathrm{ZnO})$, manganese oxide $(\mathrm{MnO})$, sulfur-iodine $(\mathrm{S}-\mathrm{I})$, and cadmium oxide $(\mathrm{CdO})$.

Five out of eight technologies mentioned in Table 9 appear to meet DOE's short-term target (by 2015) of $\$ 6 / \mathrm{kg}$ hydrogen but meeting long-term target seems quite difficult. Only thin film ferrite is very close to DOE's long-term requirement. Even in this case achieving the long-term targets require significant technological advances in multiple dimensions. The primary cost driver for all the processes that were analyzed was heliostats costs. Reducing the heliostats cost or increase in plant efficiency will bring down the CAPEX and OPEX. Most probably mass production of heliostats and improving its efficiency will help to reduce the CAPEX and help to meet DOE hydrogen cost targets. 


\section{Conclusions}

Several metal oxides have been proposed to apprehend redox cycles. To-date, the solar-to-fuel efficiencies of prototype reactors are low, on the order of $<1 \%$. The main problem in large-scale solar application would be an efficient fast quenching system to hinder the reoxidation of the reduced metal in liquid or in vapor phase. When molten metal is made to react with steam, an oxide layer will form on the surface and it floats on top of the melt, which prevents further oxidation reaction.

So far, there are no reports demonstrating good repeatability of the cyclic two-step reaction to satisfy the practical use of the process. This would be one of the most difficult achievements in this technology because the hightemperature process will cause significant sintering of the metal oxide, which severely deactivates metal oxide for repeated cyclic reactions.

Though there are hundreds of publication available in the literature on metal oxide redox cycle for hydrogen production, only few of them are practically demonstrated in prototype solar reactor. The challenges while conducting redox experiments in a solar reactor are very different than in a laboratory-scale plug flow reactor. The commercial realization of redox technology for hydrogen production seems still far away.

Acknowledgments I thank SABIC CRI for giving me an opportunity to work on this review and publish; Dr. Hicham Idriss for his valuable input on the manuscript and Dr. Sandro Gambarotta for his constant support, guidance and encouragement.

Open Access This article is distributed under the terms of the Creative Commons Attribution License which permits any use, distribution, and reproduction in any medium, provided the original author(s) and the source are credited.

\section{References}

1. Licht, S.: Solar water splitting to generate hydrogen fuel-a photothermal electrochemical analysis. Int. J. Hydrog. Energy 30(5), 459-470 (2005)

2. Kogan, A.: Direct solar thermal splitting of water and on-site separation of the products-II. Experimental feasibility study. Int. J. Hydrog. Energy 23(2), 89 (1998)

3. Lede, J., Villermaux, J., Ouzane, R., Hossain, M.A., Ouahes, R.: Production of hydrogen by simple impingement of a turbulent jet of steam upon a high temperature zirconia surface. Int. J. Hydrog. Energy 12(1), 3-11 (1987)

4. Bilgen, E., Ducarroir, M., Foex, M., Sibieude, F., Trombe, F.: Use of solar energy for direct and two-step water decomposition cycles. Int. J. Hydrog. Energy 2(3), 251-257 (1977)

5. Nakamura, T.: Hydrogen production from water utilizing solar heat at high temperatures. Sol. Energy 19(5), 467 (1977)

6. Lundberg, M.: Model calculations on some feasible two-step water splitting processes. Int. J. Hydrog. Energy 18(5), 369 (1993)
7. Palumbo, R., Léde, J., Boutin, O., Elorza Ricart, E., Steinfeld, A., Möller, S., Weidenkaff, A., Fletcher, E.A., Bielicki, J.: The production of $\mathrm{Zn}$ from $\mathrm{ZnO}$ in a high-temperature solar decomposition quench process-I. The scientific framework for the process. Chem Eng Sci 53(14), 2503-2517 (1998)

8. Palumbo, R.: Solar thermal chemical processing: Challenges and changes. J Phys IV Fr 9, Pr3-35-Pr33-40 (1999)

9. Weidenkaff, A., Brack, M., Möller, S., Palumbo, R., Steinfeld, A.: Solar thermal production of zinc: Program strategy and status of research. J Phys IV Fr 9, Pr3-313-Pr3-318 (1999)

10. Sibieude, F., Ducarroir, M., Tofighi, A., Ambriz, J.: High temperature experiments with a solar furnace: The decomposition of $\mathrm{Fe}_{3} \mathrm{O}_{4}, \mathrm{Mn}_{3} \mathrm{O}_{4}, \mathrm{CdO}$. Int. J. Hydrog. Energy 7(1), 79-88 (1982)

11. Ehrensberger, K., Frei, A., Kuhn, P., Oswald, H.R., Hug, P.: Comparative experimental investigations of the water-splitting reaction with iron oxide $\mathrm{Fe}_{1-y} \mathrm{O}$ and iron manganese oxides $\left(\mathrm{Fe}_{1-x} \mathrm{Mn}_{x}\right)_{1-y} \mathrm{O}$. Solid State Ionics 78, 151-160 (1995)

12. Ehrensberger, K., Kuhn, P., Shklover, V., Oswald, H.R.: Temporary phase segregation processes during the oxidation of $\left(\mathrm{Fe}_{0.7} \mathrm{Mn}_{0.3}\right)_{0.99} \mathrm{O}$ in $\mathrm{N}_{2}+\mathrm{H}_{2} \mathrm{O}$ atmosphere. Solid State Ionics 90, 75-81 (1996)

13. Tamaura, Y., Steinfeld, A., Kuhn, P., Ehrensberger, K.: Production of solar hydrogen by a novel, 2-step, water-splitting thermochemical cycle. Energy 20(4), 325 (1995)

14. Steinfeld, A., Kuhn, P., Reller, A., Palumbo, R., Murray, J., Tamaura, Y.: Solar-processed metals as clean energy carriers and water-splitters. Int. J. Hydrog. Energy 23(9), 767-774 (1998)

15. Abanades, S., Charvin, P., Lemont, F., Flamant, G.: Novel two-step $\mathrm{SnO}_{2} / \mathrm{SnO}$ water-splitting cycle for solar thermochemical production of hydrogen. Int. J. Hydrog. Energy 33(21), 6021 (2008)

16. Kaneko, H., Kodama, T., Gokon, N., Tamaura, Y., Lovegrove, K., Luzzi, A.: Decomposition of $\mathrm{Zn}$-ferrite for $\mathrm{O}_{2}$ generation by concentrated solar radiation. Sol. Energy 76, 317 (2004)

17. Kodama, T., Nakamuro, Y., Mizuno, T.J.: A two-step thermochemical water splitting by iron-oxide on stabilized zirconia. J. Sol. Energy Eng. 128, 3 (2006)

18. Kodama, T.: High-temperature solar chemistry for converting solar heat to chemical fuels. Prog. Energy Combust. Sci. 29(6), 567 (2003)

19. Abanades, S., Flamant, G.: Thermochemical hydrogen production from a two-step solar-driven water-splitting cycle based on cerium oxides. Sol. Energy 80(12), 1611 (2006)

20. Chueh, W.C., Falter, C., Abbott, M., Scipio, D., Furler, P., Haile, S.M., Steinfeld, A.: High-flux solar-driven thermochemical dissociation of $\mathrm{CO}_{2}$ and $\mathrm{H}_{2} \mathrm{O}$ using nonstoichiometric ceria. Science 330(6012), 1797-1801 (2010)

21. Lapp, J., Davidson, J.H., Lipinski, W.: Efficiency of two-step solar thermochemical non-stoichiometric redox cycles with heat recovery. Energy 37, 591-600 (2012)

22. Kaneko, H., Taku, S., Tamaura, Y.: Reduction reactivity of $\mathrm{CeO}_{2}-\mathrm{ZrO}_{2}$ oxide under high $\mathrm{O}_{2}$ partial pressure in two-step water splitting process Sol. Energy 85(9), 2321-2330 (2011)

23. Kang, K.-S., Kim, C.-H., Park, C.-S., Kim, J.-W.: Hydrogen reduction and subsequent water splitting of $\mathrm{Zr}$-added $\mathrm{CeO}_{2}$. J. Ind. Eng. Chem. 13(4), 657-663 (2007)

24. SP Gal, A., Abanades, A.: Dopant incorporation in Ceria for enhanced water-splitting activity during solar thermochemical hydrogen generation. J. Phys. Chem. C 116, 13516-13523 (2012)

25. Palumbo, R., Rouanet, A., Pichelin, G.: The solar thermal decomposition of $\mathrm{TiO}_{2}$ at temperatures above $2200 \mathrm{~K}$ and its use in the production of $\mathrm{Zn}$ from $\mathrm{ZnO}$. Energy 20(9), 857-868 (1995)

26. Abanades, S., Charvin, P., Flamant, G., Neveu, P.: Screening of water-splitting thermochemical cycles potentially attractive for hydrogen production by concentrated solar energy. Energy 31(14), 2805-2822 (2006)

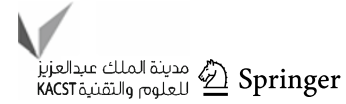


27. Cho, Y.S., Kim, J.H.: Hydrogen production by splitting water on solid acid materials by thermal dissociation. Int. J. Hydrog. Energy 36(14), 8192-8202 (2011)

28. Bilgen, E., Bilgen, C., Beghi, GE., Ducarroir, M.: Thermochemical hydrogen producing processes. Contract file No. 08SX.31155-8-6602. Prepared by Exergy Research Corporation, prepared for NRC of Canada, Montreal Road, Ottawa, K1A OR6, J.J. Murray (1979)

29. Tamaura, Y., Ueda, Y., Matsunami, J., Hasegawa, N., Nezuka, M., Sano, T., Tsuji, M.: Solar hydrogen production by using ferrites sol. Energy 65(1), 55-57 (1999)

30. Loutzenhiser, P., Meier, A., Steinfeld, A.: Review of the two-Step $\mathrm{H}_{2} \mathrm{O} / \mathrm{CO}_{2}$-splitting solar thermochemical cycle based on $\mathrm{Zn} / \mathrm{ZnO}$ redox reactions. Materials 3, 4922-4938 (2010)

31. Hed, A.Z., Tannhauser, D.S.: Contribution to the Mn-O phase diagram at high temperature. J. Electrochem. Soc. 4, 314-318 (1967)

32. Rager, T.: Re-evaluation of the efficiency of a ceria-based thermochemical cycle for solar fuel generation. Chem. Commun. 48, 10520-10522 (2012)

33. Inoue, M., Asegawa, N., Uehara, R., Gokon, N., Kaneko, H., Tamaura, Y.: Solar hydrogen generation with $\mathrm{H}_{2} \mathrm{O} / \mathrm{ZnO} /$ $\mathrm{MnFe}_{2} \mathrm{O}_{4}$ system. Sol. Energy 76(1-3), 309-315 (2004)

34. Roeb, M., Sattle, C., Klüser, R., Monnerie, N., Oliveira, L.D., Al, E.: Solar hydrogen production by a two-step cycle based on mixed iron oxides. J. Sol. Energy Eng. Trans. ASME 128(2), 125-133 (2006)

35. Kodama, T., Nakamuro, Y., Mizuno, T.: A two-step thermochemical water splitting by iron-oxide on stabilized zirconia. J. Sol. Energy Eng. Trans. ASME 128(1), 3-7 (2006)

36. Gokon, N., Mizuno, T., Nakamuro, Y., Tamaura, K., Kodama, T.: Iron-containing yttria-stabilized zirconia system for two-step thermochemical water splitting. J. Sol. Energy Eng. Trans. ASME 130(1), 011018 (2008)

37. Perkins, C., Weimer, A.W.: Likely near-term solar-thermal water splitting technologies. Int. J. Hydrog. Energy 29(15), 1587-1599 (2004)
38. Steinfeld, A.: Solar hydrogen production via a two-step watersplitting thermochemical cycle based on $\mathrm{Zn} / \mathrm{ZnO}$ redox reactions. Int. J. Hydrog. Energy 27(6), 611 (2002)

39. Lédé, J., Elorza-Ricart, E., Ferrer, M.: Solar thermal splitting of zinc oxide: A review of some of the rate controlling factors. J. Sol. Energy Eng. Trans. ASME 123(2), 91-97 (2001)

40. Haueter, P., Moeller, S., Palumbo, R., Steinfeld, A.: The production of zinc by thermal dissociation of zinc oxide-Solar chemical reactor design. Sol. Energy 67(1-3), 161-167 (1999)

41. Perkins, C., Lichty, P.R., Weimer, A.W.: Thermal ZnO dissociation in a rapid aerosol reactor as part of a solar hydrogen production cycle. Int. J. Hydrog. Energy 33(2), 499-510 (2008)

42. Souriau, D.: Procédé et dispositif pour l'utilisation d'énergie thermique à haute température, en particulier d'origine nucléaire. Device and method for the use of high temperature heat energy, in particular of nuclear origin. France Patent FR2135421

43. Gupta, P., Velazquez-Vargas, L.G., Fan, L.S.: Syngas redox (SGR) process to produce hydrogen from coal derived syngas. Energy Fuels 21(5), 2900-2908 (2007)

44. Perry, R.H., Green, D.: Perry's Chemical Engineers Handbook, 6th edn. McGraw-Hill, New York (1984)

45. Yuan-shi, L., Yan, N., Guang-yan, F., Wei-tao, W., Gesmundo, F.: Effect of grain size reduction on high temperature oxidation of binary two-phase alloys. Trans. Nonferrous Met. Soc. China 11(5), 644-648 (2001)

46. Zhong-qiu, C., Yan, N., Li-Jie, C., Wei-tao, W.: Effect of grain size reduction on high temperature oxidation of behaviour of $\mathrm{Cu}$ 80Ni alloy. Trans. Nonferrous Met. Soc. China 13(4), 908-911 (2003)

47. Syed-Hassan, S.S.A., Li, C.-Z.: Effects of crystallite size on the kinetics and mechanism of $\mathrm{NiO}$ reduction with $\mathrm{H}_{2}$. Int. J. Chem. Kinet. 43(12), 667-676 (2011)

48. Mrowec, S.: Defects and Diffusion in Solids: An Introduction. Elsevier, Amsterdam (1980) 